\title{
McGill
}

\section{The role of communities of practice in the professional education of academic librarians}

\author{
Bilodeau, E. and Carson, Pamela \\ Education for Information, 31 (1,2), 25-51. (2015) \\ doi: 10.3233/EFI-150949 \\ http:// http://content.iospress.com/articles/education-for- \\ information/efi949? resultNumber $=0$ \&totalResults $=59$ \&start $=0$ \& \\ $q=$ bilodeau\&resultsPageSize $=10 \&$ rows $=10$ \\ Copyright 2015, IOS Press
}

Uploaded to eScholarship@McGill.ca on 13 November 2015. All items in eScholarship@McGill.ca are protected by copyright with all rights reserved unless otherwise indicated. 


\title{
The role of communities of practice in the professional education of academic librarians
}

\author{
Edward Bilodeau \\ Corresponding Author \\ McGill Library, McGill University, QC, Canada
}

\author{
Pamela Carson \\ Concordia Libraries, Concordia University, Montreal, QC, Canada
}

\begin{abstract}
This study was undertaken to better understand the range of learning practices that academic librarians use throughout their careers, and to explore the ways library schools give students the opportunities to engage in learning methods that they are likely to use in their careers as librarians. The study uses semi-structured interviews with academic librarians to explore their experiences of learning in library school, as new librarians, and later as they advanced through their careers. The study found that learning is an ongoing and essential aspect of librarianship, and that it is generally self-directed, informal, highly dependent on social interactions with peers, and embedded in practice. Participants in the study reported that most of what they needed to know was learned once they started working as librarians, and that their library school experience did little to prepare them for these ways of learning. The study also found that the conceptual model of communities of practice provides a useful perspective for
\end{abstract}


understanding the learning of librarians and for designing a library school experience that is more effective at preparing students for their future careers as librarians. Implications for library school curriculum and course design are discussed.

\section{Keywords}

Professional education, continuing professional development, informal learning, non-formal learning, communities of practice, peer-to-peer networks, academic librarians 


\section{Introduction}

Learning is a lifelong process that goes beyond the formal school setting. Knowledge workers faced with the quick evolution of the workplace are expected by their employers to be willing to continuously learn [13]. In order to respond effectively to "rapid environmental changes affecting LIS fundamentally" [1], librarians must continually update their knowledge and skills [6]. A LIS education cannot fully prepare librarians-in-training for an uncertain future or for the specific local and political practices of institutions. By its very nature, a school education exposes the tension between theory and praxis, reifying knowledge in an artificial environment outside of its actual context, and rewarding students for being good at school which does not necessarily translate into being good professionals. It is not unreasonable, however, to expect the education received in library school to go beyond providing graduates with a certain mastery of the profession's body of knowledge but to in addition provide librarians with the skills required for effective lifelong learning [3].

Librarians can also expect to be continually developing their understanding and expertise in the course of their work, both as they apply their knowledge to the problems of their domain as well as learn about and adapt to new technologies, services, and practices, as indicated in the work of Simons and Ruikters [31], Broady-Preston [2], and Murray [27].

Education research can be divided between two metaphors to describe learning: the acquisition metaphor and the participation metaphor [28]. The acquisition metaphor describes the learner as the passive collector and owner of knowledge as a commodity; the participation metaphor considers the learner as situated within a context, participating in the co-creation of knowledge within a community [30]. The acquisition metaphor covers traditional classroom 
learning where the teacher is the active participant lecturing to many passive students. Academic librarians may engage in this type of learning by taking formal courses or workshops, but this research project is primarily interested in learning-as-participation, analyzed specifically through the lens of situated learning, legitimate peripheral participation, and communities of practice. Much of the learning that takes place while working is experiential and involves the acquisition of tacit knowledge and skills through practice [31] and social interaction within communities.

This research seeks to answer the call for more information on librarians' learning put forth by Riley-Huff and Rholes [29], specifically what type of in-service training are librarians engaged in and "how much can be taught in LIS courses or practicum, and how much must be expected through on-the-job experience." It is important for potential and current LIS students to get an idea of the types of learning in which they will have to engage. Also, for LIS educators, it is helpful to have a model of how academic librarians are engaging in learning-as-participation on the job in order for educators to communicate or emulate this type of learning in the classroom. For academic librarians at different stages of their careers it is useful to reflect on the types of participatory learning in which they and their peers are engaged. Finally, for library administrators it is important to recognize the various ways learning takes place in the workplace in order to support librarians' professional development.

\subsection{Research questions}

The key research questions are:

Q1. What learning methods did librarians make use of to complete library school? 
Q2. What learning methods did librarians make use of when they first began to work as librarians and had to adapt to the practical and specific aspects of their new role and work environment?

Q3. What learning methods do librarians use to develop their expertise and also keep their knowledge and skills up-to-date with changes in the scope and nature of their work?

Q4. To what extent were the learning methods employed by librarians at the start and throughout their careers acquired in library school?

Q5. What communities of practice are librarians a part of and what role did these communities of practice play in their lifelong learning?

\section{Literature review}

\subsection{Situated learning}

Jean Lave and Etienne Wenger [22] theorized a new way of looking at learning that could "inform educational endeavors by shedding a new light on learning processes and by drawing attention to key aspects of learning experience that may be overlooked." In ethnographic studies of apprenticeship, they noted the strong tie between learning and working practices, which drew their attention to the situated nature of learning and the effectiveness of learning through an engagement in practice with peers. Situated learning is where knowledge is contextualized and has a social character (contrast this with abstract or reified knowledge decontextualized in the classroom). A requirement for newcomers' effective situated learning is legitimate peripheral participation. Legitimate meaning that learners are not exploited or subject to detrimental power 
relations, peripheral meaning that learners are able to witness the work of more knowledgeable peers, and participation meaning that learners are part of the co-creation of knowledge and a negotiated meaning.

\subsection{Communities of practice}

Situated learning happens through participation in a community of practice (CoP). Novice members engage from the periphery or edge at first, but as they become more experienced and knowledgeable they start to take a more central role and begin sharing their knowledge with others. CoPs require three components: (1) a community, (2) a practice, and (3) a domain. The community is formed by people with a shared identity who are learning together through activities and discussions, the practice is the work of this community performed with shared tools, methods and skills, and the domain is the subject area or competence shared by the community [34]. CoPs exemplify Sfard's participatory metaphor used to describe learning [30].

\subsection{Is LIS education enough?}

There is some question as to whether LIS education is reflecting a quickly changing professional practice to adequately prepare academic librarians for the workplace as indicated in the work of Corrall [7]; Park, Tosaka, Maszaros and Lu [28]; Riley-Huff and Rholes [29]; Hedlund and Copeland [16]; Krasulski [20]; and Matteson, Musser and Allen [25]. Riley-Huff and Rholes [29], focused on the increasing demand for librarians with IT skillsets, noted that while technology course offerings have increased, "[ $t]$ here appears to be a clear need for 
additional courses at a more advanced level." Park, Tosaka, Maszaros and Lu [28], concerned with the education and professional development needs of cataloguing and metadata librarians, called on LIS programs to provide continuing education on metadata topics, particularly "shortterm online courses". Matteson, Musser and Allen [25] have called on "LIS educational institutions $[\ldots]$ to fulfill this need by designing [continuing education] in library management that both meets the needs and preferences of librarians." Corrall [7] presented the case of the University of Sheffield's Information School and how it is responding to changes in professional practice, particularly hybrid and blended librarian roles, by offering specialized Master's degrees in "Chemoinformatics, Health Informatics, Multilingual Information Management, Electronic \& Digital Library Management and Information Literacy" as well as continuing professional development options through courses as "professional enhancement" and individual modules for librarians to update librarians' knowledge and skills.

\subsection{Benefits of internships and field experiences in LIS}

One method to supplement LIS education and also bridge theory and practice is the internship, also known as a practicum, as service learning or as field experience. Cooper [5] reviewed written reflections by LIS students who participated in service learning during their studies. These students felt that the one-to-one mentor-student relationship and access to other professionals were positive experiences. They also noted the advantages of being able to practice the skills learned in the classroom and solve problems using what they learned in school. Overall, the students preferred the "hands on" learning experience to classroom lectures. Hoffmann and Berg [18] interviewed students who took part in field experiences, looking 
specifically at the impact on students' professional identity. Students described the placements as a way to see how "puzzle pieces" learned in a classroom setting could fit together and show "what it means practically to be a librarian." They also were exposed to what a librarian's dayto-day practice looked like. Students considered the workplace the ideal location for learning how to be a librarian. Students were able to easily join the librarian $\mathrm{CoP}$ in the workplace: "they referred to librarians as their 'colleagues' and saw themselves becoming part of a community of librarians". The authors concluded from their findings that "practical experiences reinforce and illuminate concepts that students learn about during their coursework."

\subsection{Professional development}

\subsubsection{Conferences}

Conferences are particularly favored as learning opportunities among information systems academics [9] and librarians [4, 15, 6, 20, 25]. Tomaszewski and MacDonald [33] suggested subject-specific conferences as valuable professional development opportunities for academic librarians with subject responsibilities.

\subsubsection{Social media and electronic mailing lists}

Stranack [31] proposed using social media such as Facebook and Twitter for a "personal learning network" for professional development because it is free and it provides the opportunity to build relationships with other professionals around the world. Electronic mailing lists (also known as listservs) are mentioned in the LIS literature as commonly used sources of information 
[4, 28, 6, 20]. In Krasulski's 2014 survey of access services librarians, 67 percent stated that they used electronic mailing lists to keep current [20].

\subsection{Mentoring in librarianship}

Variations on mentoring in librarianship have been covered in the LIS literature. Lacy and Copeland [21] describe a program where students were matched with academic librarians who shared common interests. The students benefited by gaining experience in instruction and witnessing the day-to-day life of a librarian as well as conversing about job seeking skills and workplace expectations. Librarian mentors stated that the experience helped them better understand their work because they had to explain it to others and they enjoyed discussions on trends and developments in libraries and information technology with the students. MacKinnon and Shepley [24] describe an "accidental" informal mentoring relationship. The authors found that informal mentorship can "remove the power imbalance between senior and junior colleagues that is often present in traditional mentorship models." Lorenzetti and Powelson [23] comprehensively reviewed the best practices and current trends for formal mentoring programs in academic libraries. They found that junior untenured librarians' development was the primary goal for the academic library mentoring partnerships. An increase in peer-mentoring programs meant to support research, writing and publishing skills was noted. Goosney, Smith and Gordon [14] wrote about their "Reflective Peer Mentoring" program for librarians involved in teaching and information literacy efforts. Diverging from traditional hierarchical and dyadic mentoring, this program had a "co-mentoring structure" where "all participants [had] the opportunity to learn from their colleagues.” Fyn [11] reported on a similar peer group mentoring program involving untenured academic librarians. The focus was "fulfilling tenure expectations, 
especially publishing peer-reviewed journal articles". From time to time the group invited more experienced librarians to speak on topics. The peer-to-peer mentoring program "diffused the workload and responsibilities related to tenure-track activities so that tenured colleagues and supervisors would not be overburdened by mentoring several individuals." Fyn [11] agreed with Murphy [26] who stated that "formal hierarchical mentoring programs [...] may no longer be the best means for transmitting tacit knowledge and preparing library leaders for the future" and that new types of "positive developmental relationship[s]" should be explored.

\subsection{CoPs in the LIS literature}

CoPs have been referred to in the LIS literature in both the academic library workplace [17] and in LIS education [8, 38], though both types of CoPs were implemented and planned purposively as such. Henrich and Attebury [17] wrote about the implementation of a CoP as an approach for mentoring. Rather than using traditional dyadic mentoring, or peer-to-peer mentoring, the University of Idaho Library decided to create a CoP with the goal of helping five new faculty members through the promotion and tenure process. This community of new as well as more experienced faculty held hour-long formal meetings once a month with presentations and time for feedback, as well as research- and publication-related discussions. The authors did not state if the CoP was limited to the formal meetings or if more informal practice-related exchanges happened on a day-to-day basis. Dalkir and Bilodeau [8] implemented a virtual CoP alongside a knowledge management curriculum in order to provide a space where students, practitioners, and LIS alumni could discuss concepts and share experiences and resources. Although the students would not be situated in practice, they expected that the environment 
could provide students with a form of "cognitive apprenticeship" that would give them a deeper understanding of the course materials. Yukawa [38] implemented a CoP model via updated course strategies and tools for a blended learning LIS course "Reference and Online Services." Among others, the goals of this project were to help students negotiate: (1) their identities as professionals and as leaders, (2) meaning by connecting theory with practice, (2) practice by moving from mental models to models of practice, and (4) expertise by building on previous expertise in order to reach professional-level expertise. Students stated that the approach was effective, appreciating the discussions and the group work. However, Lave and Wenger [21] stated that legitimate peripheral participation, a required component of a $\mathrm{CoP}$, is "not itself an educational form, much less a pedagogical strategy or a teaching technique." A classroom CoP is one step removed from an authentic $\mathrm{CoP}$ where the community consists of newcomers and old-timers and the equivalent of journeypersons or those who are neither new nor "old" to the practice. A simulated professional librarian practice may be confounded with the student practice, which has other goals such as pleasing the teacher and getting good grades.

\section{Methodology}

This research uses a case study methodology in order to study the learning practices of academic librarians "in depth and within [their] real-world context" [36]. It also makes use of communities of practice (CoPs) as a theoretical proposition to guide data collection and analysis. CoPs provide a model for describing and making sense of how groups of people, who through social interactions, develop their knowledge and expertise in the domain and practices they share 
[34]. As such, CoPs provide "a way of understanding learning" [22] that occurs throughout the professional life of the librarian.

The cases that make up this study are based on a series of semi-structured interviews conducted with academic librarians working in different areas of librarianship (i.e. public service, collection development, systems) and at different stages in their careers. The librarians who participated in the study all work in one of two universities, both located in the same city. All of the librarians also graduated from the same library school, albeit at different times over the course of almost 40 years.

The interviews were carried out in January and February 2015, and were conducted at the interviewees' place of work in a private space. Interviewees were provided with the interview questions ahead of time. A total of 12 interviews were conducted, and ranged in length from 40 to 70 minutes. The interviews were all semi-structured and based around a set primary questions (see Appendix A) that asked the interviewees to describe both the formal and informal learning that took place in library school and later in their careers as librarians. Audio recordings were made of the interviews, supplemented by fieldnotes taken by one of the co-authors during the interview. The audio recordings were manually transcribed by one of the co-authors and sufficiently anonymized to remove identifying information. Interviewees were given a chance to review their interview transcripts and modify or remove text to ensure that they were comfortable with what had been captured.

The transcripts were reviewed to identify segments describing different learning methods used by interviewees in library school and throughout their careers as librarians. The learning methods included the people, resources, and activities involved in learning. These were reviewed and analyzed using thematic coding [12] to identify common themes that emerged from the 
interviewees' responses (see Appendix B). Care was taken to ensure that any content modified or redacted from the interview transcript was similarly included or disregarded from any use of interview fieldnotes.

\section{Findings}

The librarians interviewed for this study were all academic librarians with varied areas of specialization and experience. Their specializations were as follows:

- 7 liaison librarians from a variety of disciplines

- 3 collection/access services librarians

- 1 systems librarian

- 1 specialist librarian

The interviewees ranged from the novice who had been working as a librarian for less than a year to the most experienced librarian having almost 40 years of experience. Both institutions at which the librarians worked considered librarians to be tenured academics. Of the participants, eight were tenured librarians, two held tenure-track appointments, and two were limited-term appointments. Note that the names associated with the excerpts included in this section and later in the document are fictitious.

\subsection{The library school experience}


Most participants found that their library school experience lacked the practical aspects necessary to give them a solid understanding of the work done by librarians. Coursework was perceived as being disconnected from practical realities of librarianship, leaving them feeling like they were doing "school work" and not preparing for their new careers. Any practical knowledge or skills were more likely to have been acquired through work experiences in libraries, either prior to or during library school.

\subsubsection{Classes}

While most participants attended the majority of their classes, they rarely portrayed them as a meaningful source of learning. Course material failed to give the students insights into practical aspects of libraries and librarianship. Learning activities for the most part consisted of traditional forms of assessment: papers, reports, quizzes, and examinations. Many of the interviewees treated their studies as something they had to complete in order get the credentials that would allow them work as librarians.

Kendall: "It was a question of getting stuff out of the way... I didn't find [the courses I took] to be realistic; I found them to be schoolwork. It was a degree to be gotten, and that was it."

As their expectations for the courses decreased, so did the amount of effort they put into them. This meant identifying the work that was necessary and putting in only enough effort to be able to get a reasonable grade. 
Participants did remember some of their classes as being useful, especially in the first few years of working as a librarian. The practicum was singled out by many as an important opportunity for getting the practical experience that was absent from the rest of their studies. Five of the eight participants who started their careers as liaison librarians in the sample remember the reference courses as being useful when they were starting to work as librarians. Collection development, cataloging, and management courses each also received a single favorable mention.

\title{
4.1.2. Learning resources
}

In addition to the class lectures, interviewees made use of the assigned readings to successfully complete their coursework. Interviewees only reported seeking out literature and other resources beyond the course readings when it was to address a knowledge gap in a practical setting (i.e. student work) or for a self-directed project or assignment.

\author{
Hayden: “...thinking back if I did [look at resources outside the assigned \\ readings] it was probably related to the work I was doing in my actual job as a \\ librarian employee, so as a clerk or technician, I probably sought out some \\ information sometimes to help me with work because that was interesting, \\ because I had more practical application..."
}

When asked about online resources or social media, few of the interviewees described what could be called extensive use. Three reported using web resources to look up information on technologies or applications being used in one of their courses. A small number of the 
interviewees joined listservs relating to professional associations or job postings. The interviewees did not report making great use of social media to follow or connect with the library profession.

\subsubsection{LIS faculty}

When mentioned, LIS faculty members were closely associated with classes and coursework, primarily as factors to be understood and navigated as part of the formal process of completing one's studies. A few (three) participants described adopting a strategy that involved tailoring the content and effort they put into assignments to the individual preferences and approaches of the faculty member teaching the course. For example:

Tyler: "I think I had an idea of how to survive and part of that is really just giving the [professor] what they wanted, essentially. I would look at the assignment and know that essentially try to conform and cynically speaking that's giving them what they want..."

Hayden: "My actual approach, if I'm being honest, was to do what I needed to do so that the professors would give me good grades, and by that point in my life I was very good at school. I was good at knowing how to please, for the most part, instructors or professors. Figure out what they want and give it to them."

Interviewees did appreciate courses taught by practitioners, or opportunities when practitioners would guest lecture or take part in other school activities. Large class sizes also 
made it difficult for individual students to have the kind of personal interaction with faculty that might have led to getting meaningful advice or mentoring over longer periods of time.

\subsubsection{Students}

When asked about their fellow students, interviewees found that their interactions and relationships with their peers were useful in helping them to complete their studies. Three participants noted having appreciated the variety of perspectives that their peers brought to group work and class discussion, and that these interactions helped them to develop their own thinking. In a few (three) cases, interviewees also turned to fellow students with experience working in libraries to learn more about the actual context or practical aspects of librarianship.

Jesse: "I think because the program was so based in theory we were all trying to share practical examples that we had found in our working lives or practicums or things like that, so I think we were all trying to help each other."

Despite this positive relationship, few interviewees remembered or described their peers having contributed in any significant way to their understanding of the course material.

Interviewees did remember turning to their fellow students primarily for advice and support on getting through library school.

Hayden: "I would ask what they were doing, ask for advice, not just in what are you reading? or how are you doing this?, even just for reassurance, are you really nervous about this? or are you finding anything about this?" 
The second-year students were important sources of information for first-year students, especially for helping students to understand how to navigate the program, including "[advice] for surviving the first year, and hints about what to focus on, suggestions for what courses to take, how to approach certain assignments, or how to survive group work." As could be expected, there were limits to the assistance provided by other students. One interviewee noted that student support seemed to diminish in the final semester as their cohort shifted its focus from the collaborative effort of getting through library school to the competitive reality of job seeking.

\subsubsection{Learning opportunities outside of library school}

Most of the interviewees decided to supplement their formal studies with other activities that were meant to give them some practical experience. Nine of the twelve interviewees were able to find some form of part-time work in libraries during library school. Three worked as student librarians while another six worked as library technicians or as research assistants. These extracurricular opportunities gave them the chance to interact with librarians, library staff, and patrons in a real-world setting, to ask questions and learn more about the practical aspects of librarianship. Interviewees working as student librarians or as research assistants reported learning a lot that they were able to make use of later in their careers.

\subsection{Transitioning to the professional world of the librarian}

As participants moved from the school environment to the world of work, they found themselves having to acquire a fair amount of knowledge and skills before they could be 
effective in their new roles as librarians. All interviewees recognized that at least local knowledge was needed and four stated that the learning needed was quite substantial.

Drew: "There were huge knowledge gaps, just in the day-to-day activities and the local systems that I had to learn..."

Hayden: "I would say that there were major skills gaps and I don't even know that I was remotely aware of what those gaps were... and how [many] skills I needed to build and I'm really lucky that I had good supervision and good mentoring."

\subsubsection{Learning methods}

While the training offered by libraries has changed over the years, the experiences of new librarians contained a number of common elements. The formal training activities offered by the library were mostly orientation activities meant to provide an overview of the library and to ensure that some basic but necessary procedures (getting an ID card, signing up for benefits, etc.) are taken care of. Few interviewees found these sessions very useful for helping them to assume their new responsibilities.

The methods used to train the librarians interviewed for this study can best be described as informal, but (in most cases) rigorous. Supervisors, sometimes guided by checklists they had developed, ensured that new librarians completed a set of activities or tasks that were meant to explain their new job to them. These activities involved having the work explained to them or observing others performing the tasks that they would soon be expected to do themselves.

The training processes of the past appear to have been more rigorous, with exercises or work being closely reviewed and feedback given on a regular, if not daily, basis. Librarians were 
also given a longer period of time to learn and adjust before being expected to take on their full responsibilities.

Emerson: "The [technical services] librarian trained me and really put me through the grill! It was informal, but rigorous. In the mornings I practiced and did my assignments, and in the afternoons it was reviewed, and it came back with corrections. And maybe we met once a week to talk about areas that I wasn't catching on quickly enough or having issues with."

Morgan: "They did wonderful training... Could have been three months. We would sit and watch people answering questions. That was wonderful. Every type of resource was reviewed with us."

Newer librarians still met with people, observed, and asked questions, but they were expected to be productive much sooner. Two of the interviewees believed they received little in the way of training when they started because it was not deemed necessary, either because the supervisor believed that they already possessed the necessary skills or that they would be able to figure out how to do their work on their own. Librarians in this situation often had to rely upon selfdirected learning, or learning through problem solving and trial-and-error, a sometimes-difficult experience that one librarian referred to as "baptism by fire." However, this just-in-time, handson approach to learning is one that librarians continued to employ throughout their careers. 


\subsubsection{Resources}

Librarians turned to a number of resources to learn how to perform their jobs. Some were able to learn by reviewing the notes and materials that had been left by their predecessor or shared by their co-workers. Looking at what librarians in other institutions had done was another common approach used by interviewees as they tried to address knowledge gaps in their new role. This could be done by looking at the literature, at books, articles, conference presentations, or other online sources of information.

All interviewees reported joining one or more listservs (email discussion lists) that were recommended to them by their supervisor or co-workers. Listservs were described as being specific, current, and highly relevant to their work, making them more useful than other forms of online communications and social media.

Dylan: "Social media activity is peripheral to practice. A lot of what I do is well documented and for the details I can go to the listservs because that's where people are talking about it."

Listservs provided not only a useful way of keeping up to date but also a place to turn for answers to questions and problems they had encountered in their work.

Conferences were another important learning opportunity giving new librarians the opportunity to not only acquire practical knowledge but also to meet fellow practitioners and develop an understanding of their profession outside the narrow confines of their own place of work. They also took advantage of formal learning activities such as webinars, vendor training sessions, and other workshops offered internally by the library or externally by professional 
associations or conferences, although the usefulness of these diminished as they became more experienced and had less need for general treatments of topics.

\subsubsection{People}

Sam: "The biggest source of knowledge was the people around me"

Across all of the interviews, people emerge as one of the most important sources of expertise and advice for librarians. Even in cases where the librarian was expected to figure things out for themselves, their self-directed learning involved turning to people for information, insights, and help. The centrality of people in the librarian's learning environment remained consistent throughout their careers.

Librarians learned by watching other people work, either through a planned shadowing activity or more informally throughout the course of work. People explained, demonstrated, and taught the librarian directly. Interviewees found it very helpful when they would be able to do things with their peers, such as purchasing materials, carrying out searches, planning and delivering a workshop, even writing articles. Co-workers would also guide them to valuable sources of information and expertise, recommending resources (listservs, journals, etc.) as well as other people to talk to in the library, in the university, or in the broader profession.

Participants typically described longer, mentor-like relationships with their supervisors and experienced librarians they were assigned to shadow and learn from. One newer librarian described a learning relationship that persisted beyond her initial training, with the experienced librarian providing advice and guidance over a longer period of time: 
Alex: "I feel sometimes like [librarian's] duckling, since they've taken me under their wing, and will still check in with me and look over my work."

While mentoring was typically characterized as a positive activity, one of the interviewees raised a concern that the knowledge being transferred informally in this way was not being vetted and may not be correct or appropriate, something that in most cases the mentee is not able to determine because of his/her lack of experience or familiarity with the organizational context:

Drew: "I worry about it because I think that some people give a bad example, so if you have a very high service level ... at the same time [are not] involved in other activities because you are tenured ... so that is a service level that is unattainable for [a new librarian] on the tenure track to maintain and it can cause a lot of stress in [new] librarians ... who think they have to do this and they may not have better examples."

Supervisors and co-workers are not the only people that the new librarian interacts with and learns from. Committees and projects often gave the librarian an opportunity to meet and work with librarians in other branches and departments. Liaison librarians also remembered learning from faculty members and graduate students that they supported and collaborated with for teaching. 


\subsection{Professional development of librarians}

The work of the librarian described by the interviewees is one that is always evolving, where there is always something new to learn, some new skill to acquire or develop. The librarians interviewed consider themselves "lifelong learners" and use a variety of approaches and techniques to keep their knowledge up to date and to develop their expertise. What emerged from the interviews was a sense that the librarians shared similar perspectives on learning, and that learning in all of its forms was situated in the various social relationships and communities to which they belonged.

\subsubsection{Perspectives on learning}

Participants described their professional development as a process of continual learning driven by their own curiosity and desire to learn. The ongoing learning done by librarians goes beyond being driven solely by the problem solving and knowledge gaps arising out of their practice, and includes an ongoing scanning and engaging with information and learning opportunities that capture their interest. One librarian described the process as being a kind of "sponge," with the people, information sources, and experiences all being "sort of an information feed and you just sort of sponge and absorb as much as you can." Another experienced librarian described a similar approach: "We have an antenna, it's out and always checking the environment."

This scanning can take many forms, including reviewing listservs, topical alerts, table of contents alerts for relevant journals, or skimming key journals in their field or areas of interest. Only a few of the librarians also reported using social media to follow individuals, journals, or 
professional associations for news and developments in their field. When asked about their low use of social media, librarians explained that the listservs they belonged to were a far better source of relevant and timely information, and that they did not have time to engage in other channels of communication.

\subsubsection{Social aspects of learning}

Interviewees described workplaces where the librarians regularly turned to each other for help and advice, no matter their experience level.

Alex: "If I want to try something new, I'll want to run it by them and get feedback... I've never heard anyone say, 'This is the perfect search', everyone is 'what do you think?' ... I think that's a very attitudinal thing there, very much open to learning and valuing other people's opinions."

Librarians also share news, articles, and other resources that they think their peers may find interesting or useful.

Librarians learn from each other through their shared practice, by collaborating on workshops, papers, and other projects. One librarian put forward the idea of committee work, often lamented by librarians as a waste of time, as an important context for learning:

Emerson: "People fail to appreciate that there is a purpose to the committee function, and that is to allow people to learn together, and to think out loud together. There may be other reasons to get committees together, but for me that 
is the most important, and there are lots of good things that can come out of that, everything from good feelings to building relationships with people to doing good work."

While all librarians reported being supported by their peers, the experience described by liaison libraries was different from others because there were a number of people doing the same kind of work. Contrast this to collection services and systems, where the work tends to be more specialized and there is rarely another person in the library doing the same work. This difference appears to provide liaison librarians with a source of expertise that they can draw upon with relative ease.

Interactions with librarians outside their institution also increase as their careers advance. Listservs shift from being a useful source of information to a community of peers. As one librarian stated, "As you get to know people, things become more contextualized," the interactions are more meaningful. Experienced librarians are more comfortable reaching out to peers at other institutions doing similar work for advice or help. These communities can be very valuable sources of learning for librarians who would be otherwise socially isolated from their peers:

Hayden: "There are a few librarians [in our informal buddy system] that I call on a lot, to the point where it's almost embarrassing, so when they call on me I'm relieved that I can help them with something!" 
Conferences remain an important learning opportunity for librarians to connect and renew social ties with their peer groups and share what they have been working on. They also, as described above, provide an opportunity to explore new areas, meet new people and be exposed to new ideas and perspectives.

\subsubsection{Change as an opportunity for learning}

Six of the librarians interviewed (all having over 10 years of experience) had gone through one or more major work changes in their careers, changes which put them into situations where they did not possess the required knowledge or skills. The changes rarely came with any formal training or support for their new responsibilities. Librarians reported relying on their peers and their self-driven learning styles to get them through the change.

Although disruptive, a few (three) librarians embraced the changes that came their way as opportunities to learn new things. As one senior librarian put it, "I like being on the steep part of the learning curve. I like... to challenge myself... to explore." Changes also provided opportunities for learning new ways of working. One interviewee who had long struggled with selection (collection development) described one such event:

Sasha: "The person I was sharing an office with didn't seem to be doing any better than me. But years later, when I was about to replace a librarian who was going on sabbatical, she showed me how she did selection, and that changed my life." 


\subsection{Recommendations for library schools and library school students}

\subsubsection{Perceptions of library school}

General perceptions of the usefulness of library school appear to vary with experience. Librarians who have been working as librarians for only a few years feel strongly that they did not learn much in library school, and that it did not prepare them for their careers as librarians. Librarians with more experience have a more nuanced perspective, and were able to look back and see library school as the start of a learning process.

While acknowledging that they did not learn much in the way of practical skills, four interviewees expressed doubts that it was possible for library school to provide someone with all the knowledge and practical skills they need to be an academic librarian. Part of the challenge is that the knowledge required is always changing:

Drew: "There isn't a static body of knowledge that you can learn in two years; students need to be ready to always be learning."

Another challenge that is some things can only be learned in a real-world context.

Sam: "I think there are things that you can't really teach people until you are thrown into the deep end of a situation and have to learn."

After reflecting on library school, a number of librarians noted that library school did form their ideas and attitudes towards libraries and what it means to be a librarian. One of the 
more experienced librarians stressed the importance of exposing students to "core values and knowledge and theory that is so central [to librarianship]," even if at the time the students do not fully grasp its importance.

\subsubsection{The importance of practical knowledge and experience}

Despite those acknowledgements, the strongest recommendation from participants was that library school should do more to expose students to the workplace realities of librarianship and to provide them with more practical knowledge and skills. The learning should be situated not in the classroom but in the real world of librarianship where, as one participant described it, students would be able "to learn by using more than one sense at a time."

One suggestion from participants was that library schools should partner with academic libraries to provide students with learning opportunities. A practicum or internship was also recommended as a good opportunity for the students to get this experience, as were part-time employment opportunities such as the student reference librarian program run by one of the nearby academic libraries. These activities would allow students to learn about the realities of library work and to develop practical skills through hands-on experience in real situations. The curriculum could also be changed to provide students with experiences that are more realistic and practical. Coursework should have them develop concrete and meaningful deliverables. The structure of courses should also mimic the real world, stressing collaborative work, short deadlines, and multiple projects. 
Sam: "What I like about the classes... these intense multiple deadlines. I think that any class has to continue, because that's how life is. You are working with multiple deadlines on multiple levels."

Research skills are also essential for academic librarians. One recommendation was that students be put through an information literacy "boot camp" at the start of their studies. Students should also be taught how to get "plugged in" to the literature, how to keep track of developments in librarianship and to always be learning. A research methods course should show students how to make use of the literature and integrate it into their practice. This evidence-based approach to librarianship should be made explicit and integrated into the curriculum so that students come to see it as a fundamental aspect of librarianship.

\section{Limitations}

The librarians selected to be part of this study all work in one of two academic institutions that are in close proximity to the authors, and so constitute a sample of convenience, as this proximity facilitated both recruitment and face-to-face interviewing. Both organizations, while different in size and resources, are public institutions within the same funding reality, i.e. they both face funding shortages and may not have the funds to put into place more comprehensive human resources support programs for their staff. Libraries with more formal and robust training and mentoring programs in place would likely provide a very different learning experience for librarians. 
It is also important to note that all of the librarians involved in this study also graduated from the same library school, although at different times over a span of almost 40 years. During that time the library school has changed significantly, both in response to changes in the nature of libraries and the practices of librarianship, but also as the library school broadened the scope of its curriculum to include other information professions. However, certain aspects of the school, as well as the students' experience of it, have remained consistent. Group work, for example, was mentioned by all participants. It is likely that selecting librarians who had studied at a variety of library schools would have provided a more comprehensive range of experiences, as would have seeking out librarians from a variety of institutions. However, by limiting the cases to a single library school and two places of work it can be better understood how differences in learning styles, years of experience, and even areas of librarianship have on how librarians acquire the knowledge and skills, and how those practices have changed over time.

\section{Discussion}

The experiences of the librarians interviewed span a timeframe of almost 40 years, and their testimonials provide the authors with a rich description of the learning methods that they made use of in their studies and throughout their careers. A library school that takes a traditional pedagogical approach, or Sfard's acquisition metaphor [30], is not likely to help students develop the learning approaches and strategies they will need once they graduate from library school. Fortunately, the theoretical model of communities of practice provides a more realistic and potentially useful perspective for understanding and designing a library school experience that would be more effective at preparing students for careers as librarians. 
The sections that follow discuss the findings as they relate to the five research questions (here labeled as Q1 through Q5).

\subsection{The learning of librarians}

\subsubsection{Learning in library school $(Q 1, Q 4)$}

Interviewees considered the courses they took in library school as not being all that relevant to their future careers, and as a result limited the amount of time and energy they put into them. Given that half of the interviewees were in fact able to describe how they had benefited from at least one of the courses they had taken, the problem may have been that as students they lacked the understanding of their future careers to see how at least some of what they were learning in their courses would be useful.

Participants did note an appreciation for the variety of perspectives and experiences that the other students brought to the library school experience. However, the primary role of the student peer group was to provide moral support and help each other complete coursework, and not to explain the course material. Participants reported that group work was useful in teaching them how to work with others, but did not find that their peers helped them to understand the course material. Students provided little help in finding work, which is not surprising given that they are in fact competing with each other.

The practical experience sought out by students either by volunteering or working parttime in a library did not always provide meaningful learning opportunities. While some opportunities gave students the ability to do the work of librarians, other times their role only involved repetitive tasks that at best allowed them to learn how a library operates and 
occasionally observe the work of the librarian. Just working in a library setting is not enough to ensure that meaningful learning takes place. Lave and Wenger [22] stated that situated learning needs to have legitimate peripheral participation in order to function properly. In some cases, like described in the ethnographic study of butchers and their apprentices in Situated learning: Legitimate peripheral participation, the participation is not truly legitimate due to detrimental power relations and lack of opportunities for participation.

The library school appears to have not played a major role in preparing students for the lifelong learning that was to be central to their professional lives as librarians. The library school was seen simply as a traditional school experience, and participants were able to use their existing learning strategies to complete library school successfully. While the more experienced librarians interviewed described certain courses that helped them later in their careers, none of them mentioned the learning methods they used in library school as helping to prepare them for the learning challenges that were to come. Wenger expressed concern about the reification of knowledge in the classroom setting, stating that it leads to "a brittle kind of understanding with very narrow applicability" and that in some cases "school learning is just learning school" [34].

\subsubsection{Learning to become a librarian (Q2)}

Participants describe the beginning of their first job as a librarian as a period of intense learning. They faced significant gaps in their knowledge and skills and had to undergo an intense period of training and learning before they were able to work independently. Although some initial informal training was provided, participants were responsible for their own learning and for taking whatever steps were necessary to acquire missing knowledge. The modes of learning used by librarians once they entered the workplace were entirely different from those used in 
library school, relying on informal training and self-directed learning that involved a fair amount of trial and error. People with previous work experience were often more comfortable with this way of learning, while students who had progressed directly from their undergraduate degree to library school and then to the workplace often found this to be a challenging and sometimes uncomfortable period of learning.

Comparing the training stories of experienced librarians to those who began working as librarians only recently, there appears to have been a reduction in the amount of training provided to new librarians. The training methods are largely the same: informal training provided by supervisors and co-workers, shadowing, working alongside peers, and eventually learning by doing, following the pattern of Lave and Wenger's legitimate peripheral participation [22]. What has changed and has shortened is the duration of the training where the new librarian is taught and directed by their peers. Librarians are expected to be able to carry out their assigned duties far sooner than in the past. Once the initial training stage has passed, the more intentional forms of training cease and the individual and community-based learning methods that they learn during the early days form the core of their professional development throughout the rest of their career.

\subsubsection{Ongoing learning as a librarian (Q3)}

As they progress in their careers, librarians continue to be active and engaged learners. Their workplace and professional communities are an important source of information and knowledge that they are able to access with greater ease as their social connections are far stronger than they were when they were starting out. Librarians' learning appears to be driven by practical needs (e.g. changes in job responsibilities) as well as signals that come to them from the 
ongoing environmental scanning they do. Curiosity and personal interest remain strong motivators, and appear to be an important part of maintaining learning as a habit. Similarly, in an analysis of ICT workers, Gijbels, Raemdonck, Vervecken and Van Herck [13] found that "selfdirected learning orientation" was the only variable that predicted work-related learning behavior.

As they develop their expertise, librarians appear to move away from formal learning activities such as workshops or webinars. A lessening interest in formal learning was also found with other professionals such as scientists and engineers [10] and information systems academics [9]. The economics of these activities means that the course material is usually targeted to appeal to a wide range of people, while the expert librarian is often seeking learning on very specific and timely topics, preferring instead to be taught in a way that leverages their own existing expertise and their primary learning style. Generic, predefined learning activities like workshops rarely meet these criteria.

\subsection{The role of communities of practice in the professional education and development of} librarians

The development and learning described by the interviewees shows them to have navigated through multiple CoPs in their careers. For the purposes of this discussion, two CoPs are presented: the first centered on the practices of library school and the second centered on the practices of the academic library. 


\subsubsection{Communities of practice in library school (Q5 as well as Q1)}

Library school is a CoP formed by the students and the other people who they interact with throughout their studies including students, faculty, and visiting practitioners. Library school is situated within a larger domain of academia, and by the time students enter library school, they can be considered experts at the practices of academic coursework: attending lectures, taking notes, and determining the work to be done to achieve the desired grades.

During the course of their studies, a good part of the library student's energies are focused on completing coursework, and to varying degrees students participate as members of the library school CoP to accomplish that. At the same time, their reason for attending library school was to become librarians, to join the CoP of librarians. The only way that students can begin this migration is through social interaction with the community of practitioners. This is reflected in students' desire to interact with practitioners and to learn about actual practice, and their frustration when limited to theoretical knowledge and coursework removed from the practices of librarianship.

The formal education offered by the library school in these cases offered very few opportunities to engage with the librarian CoP. Readings about librarianship and observations shared by guest lecturers gave them little more than a distant view of practice. While site visits, volunteer opportunities, and part-time work opportunities in libraries did provide a chance for students to experience the world of librarianship, the knowledge and skills they gained from these experiences varied based on the degree to which their activities allowed them to observe, and more importantly, participate in legitimate practice, i.e. the real work of librarians. For example, visiting a library could give them a better idea of the organization of a library and, depending on the duration of the visit, the work done by people there. Similarly, participating in 
the activities of a professional association could provide them with a chance to observe, interact socially, and participate in the conversations with librarians. However, as a non-practitioner without any real-world context to situate this information, participating and learning from these exchanges could be very difficult.

Working at a library in a non-librarian role (for example, as a library page, assistant, or technician) could give them a chance to learn about the operations and organizational culture of the library, but their involvement would remain peripheral to the practice of librarianship. However, working as a student librarian would constitute a form of legitimate peripheral participation. Not only would they be doing the work of a librarian, but they would be seen as part of their community, albeit a novice. Having access to and becoming a legitimate participant in this $\mathrm{CoP}$ would provide a student with the opportunity to begin to learn the knowledge and skills necessary to becoming a librarian in a meaningful and effective way.

\subsubsection{Communities of practice in the library (Q5)}

Once they begin work, the new librarians can be seen as belonging to a CoP consisting of the librarians and other people they practice with as they carry out the practices of their area of librarianship. The new librarian begins, depending on his/her knowledge and skills, somewhere on the periphery of the CoP, but has to quickly assume the role of participating novice if not full practitioner. The new librarians develop their knowledge and skills as full and active participants in the community's practice. As the new librarians assume their roles as full practitioners, they are also able to participate more fully in the activities of their professional CoP. They can also begin to interact with practitioners from other institutions and contexts, developing a richer picture of their profession and enhancing their own knowledge and skills in the process. 
Note that the new librarian is never seen as a passive learner, but rather as an active partner in the development of new knowledge. Even initially, when they are being trained by other librarians, the new librarians bring a fresh perspective, and in some cases new knowledge, to the practice. Two of the participants described how practicum students and new librarians forced them to reflect on their own practices, and often brought attitudes towards librarianship that were different from the norm. Lacy and Copeland [21] similarly stated that mentors of LIS students learned and benefited from the program. While the CoP works to teach the novice the practices of librarianship, so too does the community learn from the novice.

\subsection{Using communities of practice to enhance student learning}

The library school experience described by interviewees is one that was firmly grounded in the practices, norms, and experiences of academia. The opportunities for students to acquire the knowledge and skills they require to function as librarians were limited. What they learned about librarianship they learned using the learning methods they developed through their academic careers. As such, when they entered the professional world of librarianship, not only did they face a significant gap in their knowledge about the profession, they also had little practice in the learning methods employed by librarians in practice.

One theme that has emerged strongly from this study is that student learning would be enhanced if students could be given the opportunity to solve real problems and complete authentic tasks within the context of the actual practice. Situating even a part of the student learning in practice would give students the opportunity to interact with practitioners who would 
work alongside the students, to assist in their learning and give the students experience in the learning methods they are likely to use as professionals.

Using communities of practice as a model to enhance library school curriculum shifts the focus away from traditional academic learning methods (classes, readings, assignments) and encourages educators to view the library school experience from an entirely different perspective. It is beyond the scope of this paper to fully explore the various ways this could be accomplished as well as the significant challenges faced by educators attempting to situate a formal professional educational curriculum in the dynamic and complex reality of professional practice. That being said, communities of practice should not be considered as a prescriptive model to be implemented [22] but rather as a perspective from which educators can view their current practices to identify opportunities for enhancing student learning. Educators in a variety of fields do integrate practice into their curriculum to different degrees (see Fig. 1).

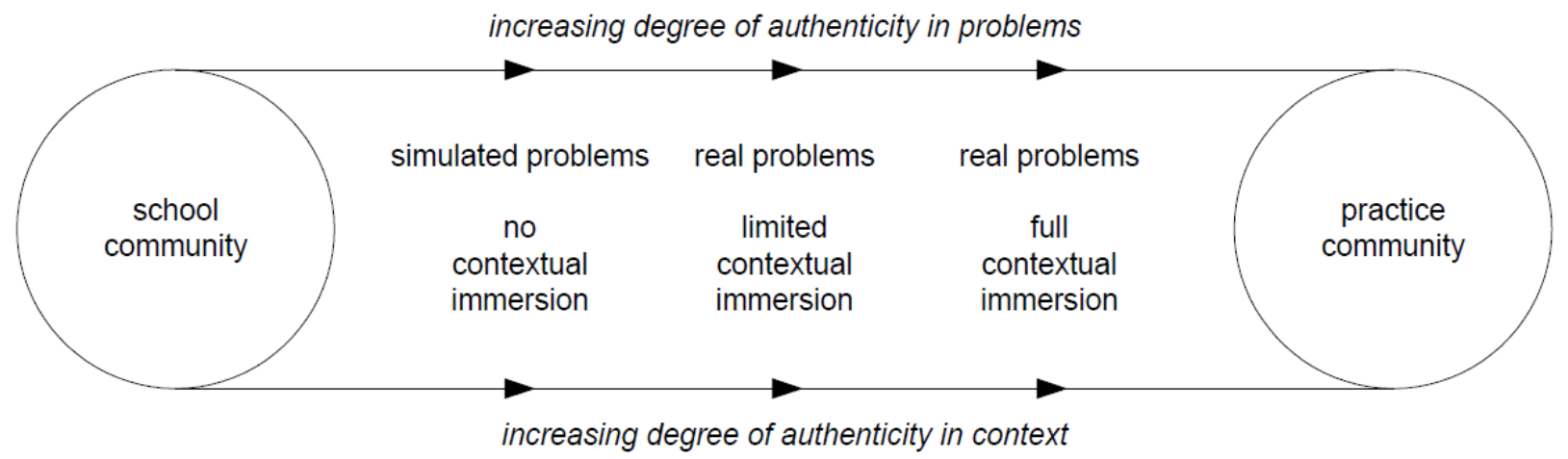

Fig. 1. Continuum of immersion into practice. Adopted from [19].

The greater the degree of authenticity, the better prepared the students will be for their eventual transition into professional practice. Educators should try to identify courses or learning objectives that would benefit the most from immersion in practice, and then, keeping in mind the 
constraints of formal academic curricula and the challenges of professional practice, find ways to move the student's learning experience along the continuum portrayed above.

\section{Conclusion}

This research seeks to provide a richer, more complete picture of the learning that academic librarians experience throughout their careers through the lens of communities of practice. Formal learning opportunities are situated within and are complemented by a web of social interactions and both informal and non-formal learning experiences, experiences which can lead to development as meaningful as any class or workshop [36, 22]. A library school experience that remains grounded in the traditional "acquisition metaphor" [30] learning structures of academia will not be able encourage students to learn new approaches and methods of learning that more closely approximate the learning they will be doing throughout their careers. Students are more likely to be motivated by a library school experience that gives them a chance to observe, participate, and learn from activities grounded in the real work of librarianship. Such an experience would allow them to acquire practical knowledge and skills, but also provide them with a better context for situating and making sense of the more abstract and theoretical aspects of librarianship.

The purpose of this study was to describe the learning practices of librarians throughout their careers and to see to what extent the communities of practice model can be helpful in understanding and improving the professional education and development of librarians. The findings suggest that this is the case, and that more research in this direction would be worthwhile for the insights it is likely to provide. An understanding of how learning practices 
vary amongst academic librarians from a wider range of institutions with different approaches and levels of organizational and financial support for formal and informal training would be useful. Studies that focus on specific types of librarianship (e.g. liaison librarians, systems librarians, etc.) are also likely to reveal different learning experiences, especially for specializations where the librarian has to go outside of his/her own institution to connect with fellow practitioners. It is also possible that academic status of librarians contributes to how their training and development needs are perceived and supported by their libraries. As tenured academics, it may be unrealistic for academic librarians to expect to be offered the same formal and centrally provided training programs as might be offered to managerial and support staff. Studying cases where academic librarians are not considered tenured faculty would help to determine the impact academic status has on training support.

The authors are aware that this paper has focused on one aspect of librarianship (academic librarianship), and that in reality most library schools, now information schools, are responsible for the education and training of a range of information professionals including both practitioners (public librarians, special librarians, archivists, knowledge managers, etc.) as well as researchers in all of these fields. Aside from some common elements, each of these domains has its own specialized knowledge and practices that must be acquired by students. For a library school to attempt to integrate its programs more closely with each of the professional communities and practices it serves would be very difficult. It would require a significant effort to design, implement, coordinate, and monitor such a learning experience to ensure that student learning continued to meet the learning objectives of the program. While the context was simplified in order to understand the phenomenon, the complexities and challenges faced by 
information schools are fully appreciated. Like all professional schools, library schools struggle to find a balance between the structures and norms of academia and the realities of the professional practice.

\section{Acknowledgements}

The authors would like to thank the librarians who participated in this study, for making the time to be interviewed and to review transcripts, and for sharing their thoughts and experiences with us.

\section{References}

[1] R. Audunson, Library and information science education-Discipline profession, vocation? Journal of Education for Library and Information Science 48 (2007), 94-107. doi: $10.2307 / 40323811$

[2] J. Broady-Preston, Professional education, development and training in a Web 2.0 environment: A case study of the UK. New Library World 110 (2009), 265-279. doi:10.1108/03074800910954280

[3] P. C. Candy, Reaffirming a proud tradition: Universities and lifelong learning. Active Learning in Higher Education 1 (2000), 101-125. doi:10.1177/1469787400001002002

[4] M. Cassner and K. E. Adams, Assessing the professional development needs of distance librarians in academic libraries. Journal of Library Administration 45 (2006), 81-99. doi:10.1300/J111v45n01_05 
[5] L. Z. Cooper, Student reflections on an LIS internship from a service learning perspective supporting multiple learning theories. Journal of Education for Library and Information Science 54 (2013), 286-298.

[6] M. Corcoran and C. McGuinness, Keeping ahead of the curve: Academic librarians and continuing professional development in Ireland. Library Management 35 (2014), 175-198. doi:10.1108/LM-06-2013-0048

[7] S. Corrall, Educating the academic librarian as a blended professional: A review and case study. Library Management 31 (2010), 567-593. doi:10.1108/01435121011093360

[8] K. Dalkir and E. Bilodeau, Linking knowledge management and LIS: Innovative use of a community of practice, in Proceedings of World Conference on E-Learning in Corporate, Government, Healthcare, and Higher Education, A. Rossett, ed., Association for the Advancement of Computing in Education (AACE), Chesapeake, VA, 2003, pp. 15641567.

[9] B. Davey and A. Tatnall, The lifelong learning iceberg of information systems academics A study of on-going formal and informal learning by academics. Journal of Information Technology Education 6 (2007), 241-248.

[10] A. deGrip and W. Smits, What affects lifelong learning of scientists and engineers? International Journal of Manpower 33 (2012), 583-597. doi:10.1108/01437721211253209

[11] A. F. Fyn, Peer group mentoring relationships and the role of narrative. The Journal of Academic Librarianship 39 (2013), 330-334. doi:10.1016/j.acalib.2012.11.016

[12] G. R. Gibbs, Thematic coding and categorizing. Analyzing Qualitative Data. SAGE Publications, Ltd., London, 2007. 
[13] D. Gijbels, I. Raemdonck, D. Vervecken and J. Van Herck, Understanding work-related learning: The case of ICT workers. Journal of Workplace Learning 24 (2012), 416-429. doi:10.1108/13665621211250315

[14] J. Goosney, B. Smith and S. Gordon, Reflective peer mentoring: Evolution of a professional development program for academic librarians. Partnership: The Canadian Journal of Library and Information Practice and Research 9 (2014).

[15] R. Harrison, Unique benefits of conference attendance as a method of professional development for LIS professionals. Serials Librarian 59 (2010), 263-270. doi:10.1080/0361526X.2010.489353

[16] O. M. Hedlund and A. Copeland, Collection management and the budget crunch: Are we adequately preparing library students for current practices? Collection Building 32 (2013), 128-132. doi:10.1108/CB-03-2013-0012

[17] K. J. Henrich and R. Attebury, Communities of practice at an academic library: A new approach to mentoring at the University of Idaho. The Journal of Academic Librarianship 36 (2010), 158-165. doi:10.1016/j.acalib.2010.01.007

[18] K. Hoffmann and S. Berg, "You can't learn it in school": Field experiences and their contributions to education and professional identity. Canadian Journal of Information and Library Science 38 (2014), 220-238. doi:10.1353/ils.2014.0015

[19] K. Hogan, Pitfalls of community-based learning: How power dynamics limit adolescents' trajectories of growth and participation. Teachers College Record 104 (2002), 586-624.

[20] M. J. Krasulski, "Where do they come from, and how are they trained?” Professional education and training of access services librarians in academic libraries. Journal of Access Services 11 (2014), 14-29. doi:10.1080/15367967.2014.867728 
[21] M. Lacy and A. J. Copeland, The role of mentorship programs in LIS education and in professional development. Journal of Education for Library \& Information Science 54 (2013), 135-146.

[22] J. Lave and E. Wenger, Situated learning: Legitimate peripheral participation. Cambridge Press, Cambridge, MA. 1991.

[23] D. L. Lorenzetti and S. E. Powelson, A scoping review of mentoring programs for academic librarians. The Journal of Academic Librarianship 41 (2015), 186-196. doi:10.1016/j.acalib.2014.12.001

[24] C. MacKinnon and S. Shepley, Stories of informal mentorship: Recognizing the voices of mentees in academic libraries. Partnership: The Canadian Journal of Library and Information Practice and Research 9 (2014).

[25] M. L. Matteson, S. Musser and E. Allen, From good to great managers: The case for a structured continuing education program in library management. Library Management $\mathbf{3 6}$ (2015), 127-141. doi:10.1108/LM-05-2014-0058

[26] S. A. Murphy, Developmental relationships in the dynamic library environment: Reconceptualizing mentoring for the future. The Journal of Academic Librarianship 34 (2008), 434-437. doi:10.1016/j.acalib.2008.06.006

[27] T. E. Murray, Professional development and the special librarian. Journal of Library Administration 54 (2014), 709-719. doi:10.1080/01930826.2014.965104

[28] J. Park, Y. Tosaka, S. Maszaros and C. Lu, From metadata creation to metadata quality control: Continuing education needs among cataloging and metadata professionals. Journal of Education for Library and Information Science 51 (2010), 158-176. 
[29] D. A. Riley-Huff and J. M. Rholes, Librarians and technology skill acquisition: Issues and perspectives. Information Technology and Libraries 30 (2011), 129-140.

doi:10.6017/ital.v30i3.1770

[30] A. Sfard, On two metaphors for learning and the dangers of choosing just one. Educational Researcher 27 (1998), 4-13. doi:10.3102/0013189X027002004

[31] P. R. -J. Simons and M. C. P. Ruijters, Learning professionals: Towards an integrated model, in Professional learning: Gaps and transitions on the way from novice to expert, $\mathrm{H}$. P. A. Boshuizen, R. Bromme and H. Gruber, eds., Kluwer Academic, Dordrecht, Germany, 2004, pp. 207-229.

[32] K. Stranack, The connected librarian: Using social media for "Do it yourself" professional development. Partnership: The Canadian Journal of Library and Information Practice and Research 7 (2012).

[33] R. Tomaszewski and K. I. MacDonald, Identifying subject-specific conferences as professional development opportunities for the academic librarian. The Journal of Academic Librarianship 35 (2009), 583-590. doi:10.1016/j.acalib.2009.08.006

[34] E. Wenger, Communities of practice: Learning, meaning, and identity. Cambridge University Press, New York, 1998.

[35] E. Wenger, R. McDermott and W. M. Snyder, Cultivating communities of practice: $A$ guide to managing knowledge. Harvard Business School Press, Boston, MA, 2002.

[36] C. Wihak and G. Hall, Work-related informal learning: Research and practice in the Canadian context. Canadian Council on Learning, Ottawa, Canada, 2011 at http://hdl.voced.edu.au/10707/193640 
[37] R. K. Yin, Case study research: Design and methods. Sage Publications, Thousand Oaks, CA, 2014.

[38] J. Yukawa, Communities of practice for blended learning: Toward an integrated model for LIS education. Journal of Education for Library \& Information Science 51 2010, 54-75.

\section{Appendix A}

Primary questions used during the interviews

- In library school, how did you learn what you needed to know to graduate? What resources did you use? Who else aside from the faculty members did you learn from?

- When you first began to work as a librarian, what did you need to learn before you could be effective in your new job? What kind of formal orientation and training process did the library have in place? What kind of informal training did you receive? Where did you turn for help and support?

- How did you go about developing your expertise? How did you keep your knowledge and skills up to date with the changes in your work? What kind of formal training did you take part in? Where else did you turn for help and support?

- What learning methods do librarians use to improve their expertise and also keep their knowledge and skills up-to-date with changes in the scope and nature of their work?

- How well did library school prepare you for the learning you would need to do throughout the rest of your career? If you didn't learn at library school, where do you learn how to be an effective learner? What do you know now about the learning that you would have to do that you wished you knew when you graduated from library school? 


\section{Appendix B}

Prompts, variables and coded themes

\begin{tabular}{|c|c|c|c|}
\hline Interview question & Prompts & $\begin{array}{l}\text { Variables } \\
\text { measured }\end{array}$ & $\begin{array}{l}\text { Themes coded in } \\
\text { transcribed } \\
\text { interviews }\end{array}$ \\
\hline $\begin{array}{l}\text { In library school, how did } \\
\text { you learn what you needed to } \\
\text { know to graduate? What } \\
\text { resources did you use? Who } \\
\text { else aside from the faculty } \\
\text { members did you learn from? }\end{array}$ & $\begin{array}{l}\text { Returning student } \\
\text { or direct from } \\
\text { undergrad? } \\
\text { Group work? } \\
\text { Readings? } \\
\text { Additional } \\
\text { resources beyond } \\
\text { what was assigned? } \\
\text { How were } \\
\text { classmates coping? } \\
\text { Did classmates help } \\
\text { you learn? } \\
\text { How did working in } \\
\text { a library during } \\
\text { your studies help }\end{array}$ & $\begin{array}{l}\text { learning } \\
\text { methods in } \\
\text { library school }\end{array}$ & $\begin{array}{l}\text { classes; learning } \\
\text { activities; learning } \\
\text { resources; LIS } \\
\text { faculty; other } \\
\text { students; learning } \\
\text { opportunities (people } \\
\text { and experiences) } \\
\text { outside of library } \\
\text { school }\end{array}$ \\
\hline
\end{tabular}




\begin{tabular}{|c|c|c|c|}
\hline When you first began to & Formal orientation? & learning & Formal and informal \\
\hline work as a librarian, what did & Knowledge gap? & methods as new & learning \\
\hline you need to learn before you & Was training & librarian & opportunities; \\
\hline could be effective in your & systematic? & & learning methods; \\
\hline new job? What kind of & Observing other & & resources; listserv; \\
\hline formal orientation and & librarians? & & conferences; learning \\
\hline training process did the & Mentoring? & & from co-workers; \\
\hline library have in place? What & How did you go & & learning from people \\
\hline kind of informal training did & about learning how & & outside the library \\
\hline you receive? Where did you & things really got & & \\
\hline \multirow[t]{5}{*}{ turn for help and support? } & done? & & \\
\hline & Did you interact & & \\
\hline & with people in other & & \\
\hline & branches or & & \\
\hline & departments? & & \\
\hline How did you go about & How do you deal & learning & Learning activities; \\
\hline developing your expertise? & with challenges? & methods for & perspectives on \\
\hline How did you keep your & Are there any online & professional & learning; social \\
\hline knowledge and skills up to & resources you use to & development & aspects of learning; \\
\hline date with the changes in your & & & change as \\
\hline
\end{tabular}




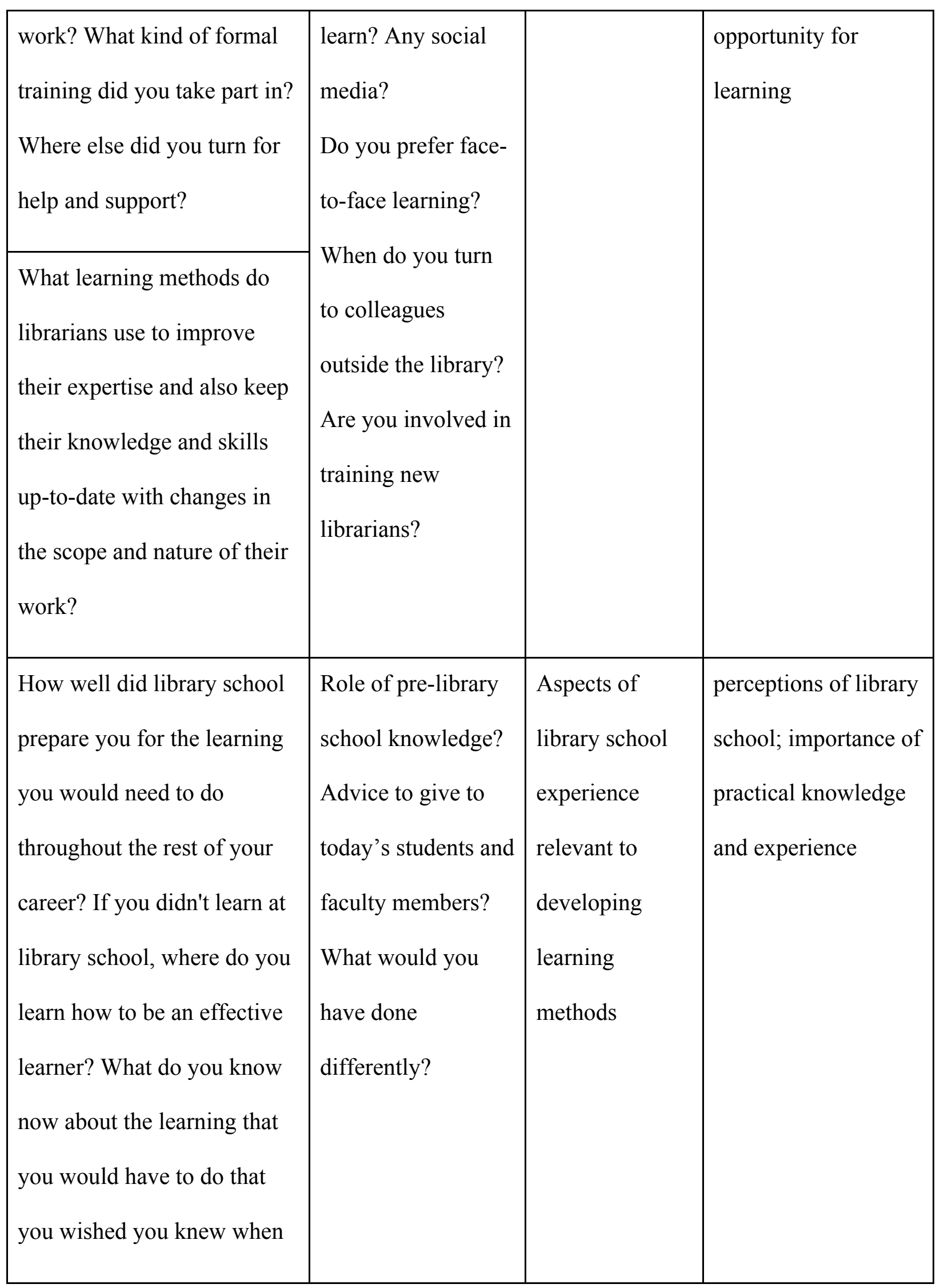




\begin{tabular}{|l|l|l|l|}
\hline you graduated from library & & & \\
school? & & & \\
\hline
\end{tabular}

